www.nature.com/ja

\title{
Ganodermycin, a novel inhibitor of CXCL10 expression from Ganoderma applanatum
}

\author{
Mathias Jung ${ }^{1}$, Johannes C Liermann ${ }^{2}$, Till Opatz ${ }^{2}$ and Gerhard Erkel ${ }^{3}$ \\ CXCL10 (inducible protein-10) is a highly inducible chemoattractant, which contributes to the recruitment of inflammatory cells, \\ such as macrophages and T-lymphocytes, and thereby has important roles in chronic inflammatory conditions. In a search for \\ new inhibitors of CXCL10 expression in MonoMac 6 cells, a novel compound, designated as Ganodermycin, was isolated from \\ fermentations of the basidiomycete Ganoderma applanatum. The structure was determined by a combination of spectroscopic \\ techniques. Ganodermycin inhibited the lipopolysaccharide (LPS)/interferon (IFN)- $\gamma$-induced CXCL10 promoter activity in \\ transiently transfected MonoMac6 cells in a dose-dependent manner with $\mathrm{IC}_{50}$ values of $15-20 \mu \mathrm{g} \mathrm{ml} \mathrm{I}^{-1}(53-71 \mu \mathrm{M})$. \\ Ganodermycin also reduced LPS/IFN- $\gamma$-induced CXCL10 protein synthesis and excretion.
} The Journal of Antibiotics (2011) 64, 683-686; doi:10.1038/ja.2011.64; published online 27 July 2011

Keywords: CXCL10; Ganoderma; inhibitor; new metabolite

\section{INTRODUCTION}

CXCL10/interferon (IFN)- $\gamma$-inducible protein-10, a member of the non-ELR CXC chemokine family, is a critical component of immune responses by acting as a chemoattractant for activated natural killer and Th1 cells into sites of inflammation. CXCL10 is produced by several cell types, such as endothelial cells, keratinocytes, eosinophil and neutrophils. Furthermore, it is produced by cells of the monocytic system (macrophages and monocytes), which have a major role in immune defense by presenting processed antigens to $\mathrm{T}$ cells, phagocytosis of foreign material and coordination of the immune response by secretion of cytokines and chemokines. CXCL10 also participates in the regulation of $\mathrm{T}$-cell responses due to modulation of $\mathrm{T}$-cell proliferation in response to an antigenic challenge and favoritism of Th1-type cytokine production while downregulating Th2 cytokines. ${ }^{1-3}$ The chemokine was first identified as an early response gene induced by IFN- $\gamma$ in a variety of cells but it can also be induced by IFN- $\alpha$ and IFN- $\beta$, as well as by bacterial lipopolysaccharide (LPS). Although essential for effective host defense against infections, an increased expression of CXCL10 may also contribute to the induction and exacerbation of chronic inflammatory reactions associated with graft rejection or allergic and autoimmune diseases. ${ }^{3}$ An increased expression of CXCL10 has been observed in patients with COPD, asthma and in acute inflammation in response to pathogens. Furthermore, CXCL10 has been reported to occur in higher levels in patients with inflammatory bowel diseases, as well as in the serum and synovial fluid of rheumatoid arthritis patients. ${ }^{3,4}$ The expression of CXCL10 is mainly regulated at the transcriptional level by the activation of the nuclear factor (NF)- $\kappa \mathrm{B}$, STAT1 and IRF-3 transcription factors after cytokine induction and engagement of the Toll-like receptors by LPS. ${ }^{5}$

Therefore, CXCL10 might be an attractive target for the development of new therapeutics against various inflammatory conditions including inflammatory bowel disease or rheumatoid arthritis. ${ }^{6}$ In a screening of fungal extracts inhibiting the inducible CXCL10 promoter activity, we found that Ganoderma applanatum produced a new metabolite with inhibitory activity on the CXCL10 promoter-dependent luciferase reporter gene expression in transiently transfected MonoMac6 cells. In this paper, the fermentation, structure elucidation and some biological properties of the compound that we have named ganodermycin are described.

\section{RESULTS AND DISCUSSION}

Microbiology

Strain IBWF09003 was isolated from fruiting bodies collected in French Guiana and showed the typical morphological characteristics of the genus Ganoderma. The strain was identified by internal transcribed spacer (ITS) sequence comparison. The ITS sequence was $100 \%$ identical to Ganoderma applanatum ITS1-5.8S rDNA-ITS2 (GenBank Accession No.: AY884179.1).

\section{Structure elucidation}

Ganodermycin was isolated from the culture fluid extract by bioactivity-guided fractionation as described in the experimental section. Mass spectrometric data gave an elemental composition of $\mathrm{C}_{15} \mathrm{H}_{20} \mathrm{O}_{5}$, requiring six unsaturations and giving evidence for a sesquiterpenoid

\footnotetext{
${ }^{1}$ Institute of Biotechnology and Drug Research (IBWF), Kaiserslautern, Germany; ${ }^{2}$ Institute of Organic Chemistry, University of Mainz, Duesbergweg, Mainz, Germany and ${ }^{3}$ Department of Biotechnology, University of Kaiserslautern, Kaiserslautern, Germany

Correspondence: Dr G Erkel, Department of Biotechnology, University of Kaiserslautern, Paul-Ehrlich-Strasse 23, Kaiserslautern D-67663, Germany.

E-mail: erkel@ibwf.de
}

Received 10 March 2011; revised 25 May 2011; accepted 17 June 2011; published online 27 July 2011 
structure. The ${ }^{13} \mathrm{C}$ NMR spectrum gave two olefinic carbon resonances at 155.9 and 138.4 p.p.m., respectively, along with a ketone carbonyl at 197.5 p.p.m. and an aldehyde carbonyl at 194.8 p.p.m. The proton at 6.88 p.p.m., bound to the carbon resonating at 138.4 p.p.m. as judged by HSQC, showed heteronuclear multiple bond correlation (HMBC, Figure 1) to all aforementioned carbon atoms, suggesting a derivative of fumaraldehyde. HMBC contacts from the aldehyde proton and the olefinic proton showed that the quaternary olefinic carbon was bound to a methine carbon atom, which was part of a cyclohexane-4carboxylic acid moiety. The ketone carbonyl of the endione fragment was HMBC correlated to a methine proton at 3.51 p.p.m., being part of an oxirane with two geminal methyl groups bound to the other carbon.

The double bond's E-configuration was evident from correlations between the aldehyde proton and the olefinic proton in the NOESY spectrum. The residues on the cyclohexane are trans to each other, as both methine protons in the ring (3.22 and 2.41 p.p.m.) exhibited large coupling constants of around $12 \mathrm{~Hz}$, which requires axial positions in both cases. The resulting stereochemistry was confirmed by the analysis of the relevant NOESY contacts (Figure 1). Matching coupling constants and chemical shifts were reported for juvabione analogs ${ }^{7}$ and hymenoic acid. ${ }^{8}$ The relative configuration of the stereogenic center in the oxirane unit could, however, not be determined.

There are some examples of other sesquiterpenoids, ${ }^{7-9}$ as well as diterpenes, ${ }^{10,11}$ with cyclohexane carboxylic acid fragments. The structure of ganodermycin is also related to juvabione, a juvenile hormone from balsam fir. ${ }^{12}$

\section{Biological activity}

To search for compounds and to characterize the influence of ganodermycin on CXCL10 expression, we used a human CXCL10 promoter-dependent transcriptional reporter in transiently transfected monocytic MonoMac6 cells, which reflects the activation of the transcription factors binding to the regulatory sites of the CXCL10 gene. Cells of the monocytic system (macrophages and monocytes) form a central part in immune defense by presenting processed antigen to $\mathrm{T}$ cells, phagocytosis of foreign material and orchestrating the immune response by secretion of cytokines. Typically, these cells, when triggered by an immunogen, produce proinflammtory cytokines (for example, tumor necrosis factor- $\alpha$, interleukin- $1 \beta$ and interleukin6), chemokines (for example, CXCL10 and CXCL8) and proinflammtory enzymes (for example, COX-2). ${ }^{13}$ Transfection of MonoMac6 cells with a hCXCL10 promoter-driven luciferase reporter plasmid and stimulation with $1 \mu \mathrm{g} \mathrm{ml}^{-1}$ LPS and $10 \mathrm{ng} \mathrm{ml}^{-1}$ IFN- $\gamma$ increased luciferase activity 8 - to 10-fold compared with non-stimulated cells. As shown in Figure 2a, the inducible promoter activity was dose dependently inhibited by ganodermycin with $\mathrm{IC}_{50}$ values of $15-20 \mu \mathrm{g} \mathrm{ml}^{-1}(53-71 \mu \mathrm{M})$. The response of the 972-bp CXCL10

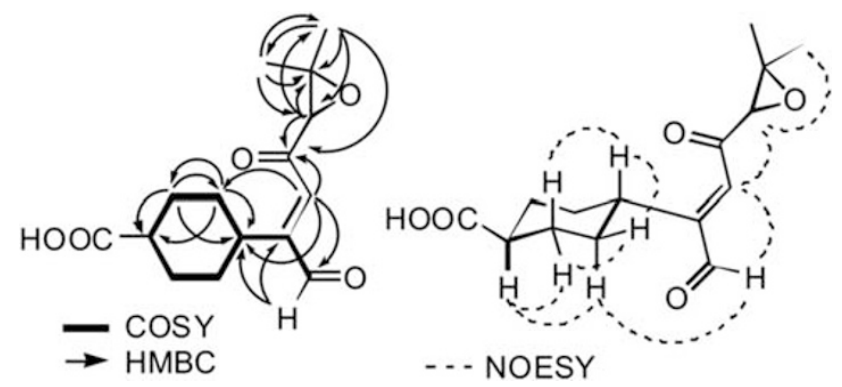

Figure 1 The 2D NMR correlations found for ganodermycin. promoter construct largely depends on two proximal NF- $\kappa B-$, three distal IFN-stimulated response elements and two Stat recognition sites. ${ }^{14}$ We therefore investigated the effect of ganodermycin on NF- $\kappa \mathrm{B}-$, Stat1- and IFN-stimulated response element-driven expression of the reporter gene luciferase in LPS/IFN- $\gamma$-stimulated MonoMac6 cells. As shown in Figure 2a, the Stat1-driven expression of the reporter gene was preferentially inhibited by ganodermycin with $\mathrm{IC}_{50}$ values of $5-10 \mu \mathrm{g} \mathrm{ml}^{-1}(18-36 \mu \mathrm{M})$, whereas the NF- $\mathrm{KB}$ - and IFNstimulated response element-dependent transcriptional reporters were inhibited with $\mathrm{IC}_{50}$ values of $20 \mu \mathrm{g} \mathrm{ml}^{-1}(71 \mu \mathrm{M})$. The constitutive activity of the EF-1 $\alpha$-promoter-driven expression of the reporter gene renilla luciferase was not affected up to a concentration of $30 \mu \mathrm{g} \mathrm{ml}^{-1}$ $(106 \mu \mathrm{M})$ ganodermycin, indicating that the compound does not interfere with transcription in a general manner.

Next, we analyzed the influence of ganodermycin on CXCL10 synthesis and excretion in MonoMac6 cells, which release significant amounts of CXCL10 following LPS/IFN- $\gamma$ treatment for $16 \mathrm{~h}$. As shown in Figure 2b, pretreatment of MonoMac6 cells with various
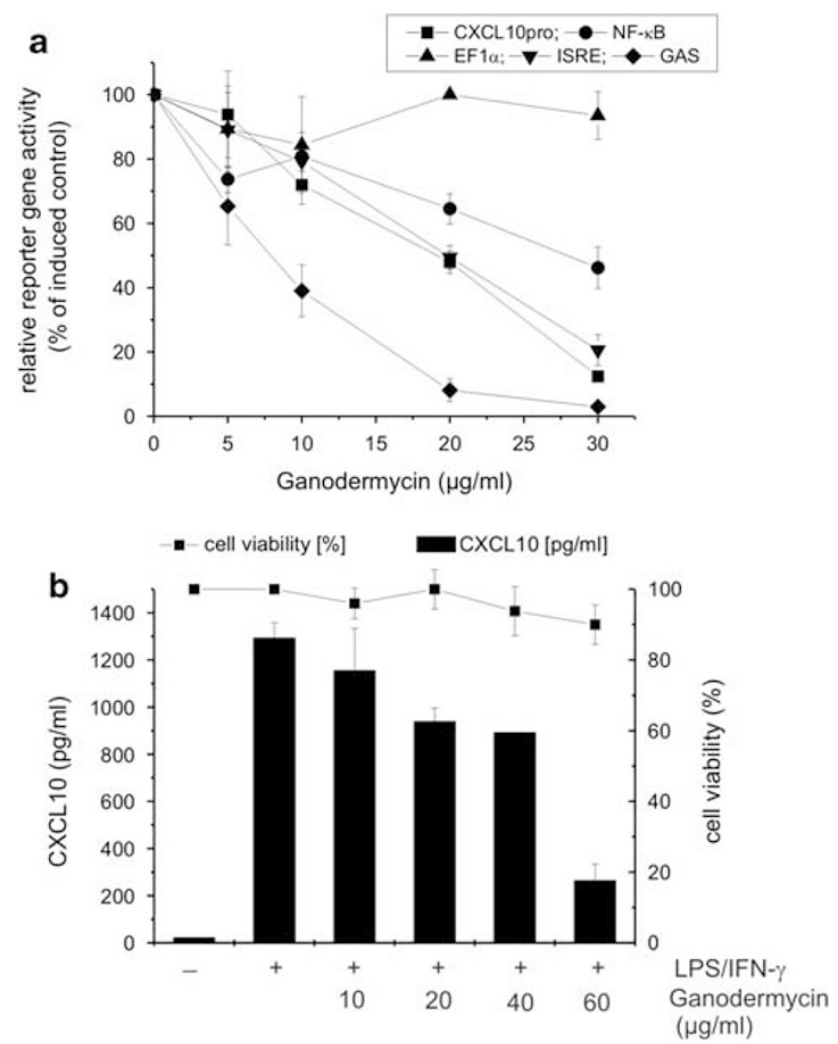

Figure 2 Effect of ganodermycin on CXCL10 promoter activity and expression. (a) MonoMac6 cells were transiently transfected with a CXCL10, nuclear factor- $\mathrm{B}$, STAT1, interferon (IFN)-stimulated response element or EF1 $\alpha$ promoter-dependent reporter construct and stimulated with $1 \mu \mathrm{g} \mathrm{ml}^{-1}$ lipopolysaccharide (LPS) and $10 \mathrm{ngml}^{-1} \mathrm{IFN}-\gamma$ for $4 \mathrm{~h}$ with or without ganodermycin. Control (100\%): stimulation only. The expression of the reporter genes was determined as described in Methods. Results represent the mean \pm s.e.m. of at least three independent experiments. (b) Effect of ganodermycin on CXCL10 production and cell viability. MonoMac6 cells were pretreated for $1 \mathrm{~h}$ with or without the test compound and stimulated with $1 \mathrm{\mu gml}^{-1}$ LPS and $10 \mathrm{ngml}^{-1}$ IFN- $\gamma$ for additional $16 \mathrm{~h}$. CXCL10 concentrations in cell supernatants were determined by enzyme-linked immunosorbent assay. Cell viability was determined by 2,3-bis(2-methoxy-4nitro-5-sulfophenyl)-2 $\mathrm{H}$-tetrazolium-5-carboxanilide sodium colorimetric assay. Data are shown as mean values \pm s.e.m. of three independent experiments. 
Table 1 Antimicrobial activities of ganodermycin (inhibition zone in $\mathrm{mm}, 50 \mu \mathrm{g}$ per $\operatorname{disc}^{\mathrm{a}}$ )

\begin{tabular}{lccc}
\hline Nematospora coryli & $\begin{array}{c}\text { Bacillus } \\
\text { subtilis }\end{array}$ & $\begin{array}{c}\text { Bacillus } \\
\text { brevis }\end{array}$ & $\begin{array}{c}\text { Micrococcus } \\
\text { luteus }\end{array}$ \\
\hline 30 & 31 & 29 & 16 \\
\hline
\end{tabular}

Disk diameter: $6 \mathrm{~mm}$.

concentrations of ganodermycin and stimulation with LPS/IFN- $\gamma$ for $16 \mathrm{~h}$ resulted in a dose-dependent inhibition of CXCL10 synthesis and excretion with $\mathrm{IC}_{50}$ values around $40 \mu \mathrm{g} \mathrm{ml}^{-1}(142 \mu \mathrm{M})$. Cytotoxic properties of ganodermycin were evaluated against MonoMac6 cells by measuring the reduction of the tetrazolium compound 2,3-bis (2-methoxy-4-nitro-5-sulfophenyl)-2H-tetrazolium-5-carboxanilide sodium into a colored formazan product, which is directly proportional to the living cells in culture. No cytotoxic activities against MonoMac6 cells could be observed up to $60 \mu \mathrm{g} \mathrm{ml}^{-1}(213 \mu \mathrm{M})$ of the compound during a 24-h incubation period (Figure $2 \mathrm{~b}$ ). In addition, antifungal activities against the yeast Nematospora coryli and antibacterial activities against the Gram-positive bacteria Bacillus subtilis, Bacillus brevis and Micrococcus luteus could be observed at concentrations starting at $50 \mu \mathrm{g}$ per disc in the agar diffusion assay (Table 1).

The structurally related compound hymenoic acid, isolated from a Hymenochaetaceae species, has recently been described as a selective inhibitor of the human DNA polymerase- $\lambda$, which has a role in base excision repair and in non-homologous end joining of DNA doublestrand breaks in DNA-damaged cells with an $\mathrm{IC}_{50}$ value of $91.7 \mu \mathrm{M} .^{8}$ Our data show that ganodermycin interferes with STAT1-, NF- $\kappa$ Band IRF-dependent signal transduction pathways, which participate in the transcriptional activation of the CXCL10 gene. In addition the compound exhibited no cytotoxic effects up to $213 \mu \mathrm{M}$. In summary, we have identified a novel inhibitor of CXCL10 expression, which may serve as lead structure for the development of transcriptionally based inhibitors of chronic inflammatory disorders. Further investigations on the cellular targets and the mode of action of ganodermycin are now under way.

\section{METHODS}

\section{Producing organism}

The producing fungus Ganoderma applanatum (IBWF09003) is deposited in the culture collection of the Institute of Biotechnology and Drug Research (IBWF eV), Kaiserslautern, Germany. The fungus was identified by PCR amplification and ITS sequence analysis of the ITS1-5.8S rDNA-ITS2 region of nuclear DNA as described previously. ${ }^{15}$ For maintenance, the fungus was grown on HA agar slants (yeast extract $0.4 \%$, malt extract $1 \%$, glucose $0.4 \%$, the $\mathrm{pH}$ value was adjusted to 5.5 before autoclaving). Solid media contained $2 \%$ of the agar.

\section{Fermentation and isolation of ganodermycin}

Well-grown seed cultures of the producing strain $(200 \mathrm{ml} \mathrm{HA}$ medium) were used to inoculate a Biolafitte C-6 fermenter (DCI-Biolafitte, Mauze, France) containing 201 of HA medium with aeration (3.01 air min ${ }^{-1}$ ) and stirring (120 r.p.m.) at $22^{\circ} \mathrm{C}$. The production of ganodermycin was followed by the inhibitory effect of various concentrations of a crude extract of the culture fluid in the CXCL10 promoter-dependent reporter gene assay as described below. The compound was isolated from the culture fluid by bioactivity-guided fractionation using the transcriptional reporter assay in MonoMac6 cells. After 9 days, the culture fluid was separated from the mycelia by filtration, extracted twice with an equal volume of EtOAc and dried over $\mathrm{Na}_{2} \mathrm{SO}_{4}$. After concentration in vacuo, the crude extract $(8.3 \mathrm{~g})$ was fractionated by subsequent chromatography on silica gel (Merck 60, eluent:cyclohexane:EtOAc, 50:50 v/v)

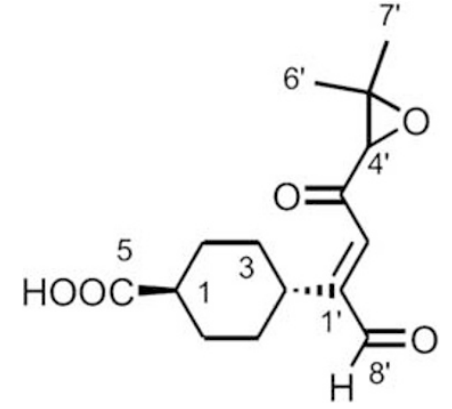

Figure 3 Structure of ganodermycin.

(Merck, Darmstadt, Germany). The enriched product ( $469 \mathrm{mg}$ ) was further purified by preparative HPLC (Macherey \& Nagel, Düren, Germany; Nucleosil RP18; column $250 \times 21 \mathrm{~mm}$, flow $20 \mathrm{ml} \mathrm{min}^{-1}$; gradients: $0.1 \% \mathrm{HCOOH}-$ MeCN $30-60 \%$ in $20 \mathrm{~min}, 60-100 \%$ in $5 \mathrm{~min}$ ) to yield $88 \mathrm{mg}$ pure ganodermycin. Using ultraviolet detection at 210 and $250 \mathrm{~nm}$, the retention time of the fractions containing ganodermycin was $18 \mathrm{~min}$.

\section{Spectroscopy}

${ }^{1} \mathrm{H}$ NMR $(400 \mathrm{MHz})$ and ${ }^{13} \mathrm{C}$ NMR $(101 \mathrm{MHz})$ were recorded with a Bruker (Bremen, Germany) Avance-II spectrometer equipped with a $5 \mathrm{~mm}$ BBO probehead. The spectra were measured in $\mathrm{CDCl}_{3}$, and the chemical shifts were referenced to the residual solvent signal $\left(\delta_{\mathrm{H}}=7.26\right.$ p.p.m. and $\delta_{\mathrm{C}}=77.16$ p.p.m.). ${ }^{16}$ APCI-MS spectra were measured from a solution of the analyte in acetonitrile/water with a Hewlett Packard MSD 1100 (Agilent, Waldbronn, Germany) using an evaporator temperature of $400{ }^{\circ} \mathrm{C}$ and a drying gas temperature of $350^{\circ} \mathrm{C}$ at a flow of $61 \mathrm{~h}^{-1}\left(\mathrm{~N}_{2}\right)$. In positive ionization mode, the capillary voltage amounted to $3.5 \mathrm{kV}$ and the corona discharge current was $4 \mu \mathrm{A}$. In negative ionization mode, the capillary voltage amounted to $2.2 \mathrm{kV}$ and the corona discharge current was $6 \mu \mathrm{A}$. ESI-HRMS data were measured from a solution of the analyte in acetonitrile with a Waters (Eschborn, Germany) Q-TOF-Ultima 3 equipped with a LockSpray interface (tri- $n$-octylamine as external reference). IR and UV spectra were measured with a Bruker IFS48 FTIR spectrometer and a Perkin-Elmer Lambda-16 spectrophotometer (PerkinElmer, Rodgau, Germany), respectively. The optical rotation was measured on a Perkin-Elmer 241 polarimeter at $578 \mathrm{~nm}$ and $546 \mathrm{~nm}$ and extrapolated to $589 \mathrm{~nm}$ using Drude's equation.

\section{Ganodermycin}

Yellow oil; (Figure 3) $[\alpha]]^{22}\left(c 0.41, \mathrm{CDCl}_{3}\right)-21$; ultraviolet $\lambda_{\max }^{\mathrm{MeOH}}(\mathrm{nm} ; \log \varepsilon$ ) 250 (4.06); infrared $v_{\max }\left(\mathrm{KBr} ; \mathrm{cm}^{-1}\right) 3434,2932,1698,1391,1203$ and 1100; APCI-MS (negative) $\mathrm{m} / \mathrm{z} 279.1$ (100) $[\mathrm{M}-\mathrm{H}]^{-}$; ESI-HRMS $\mathrm{m} / \mathrm{z} 303.1220$ (calculated for $\mathrm{C}_{15} \mathrm{H}_{20} \mathrm{O}_{5}+\mathrm{Na}^{+}$303.1208). ${ }^{1} \mathrm{H}$ and ${ }^{13} \mathrm{C}$ nuclear magnetic resonanceNMR data are presented in Table 2.

\section{Biological assays}

MonoMac6 (DSMZ ACC124) cells were maintained in RPMI 1640 medium containing $25 \mathrm{~mm}$ HEPES buffer, $2 \mathrm{~mm}$ L-glutamine, supplemented with $10 \%$ fetal calf serum, $100 \mathrm{U} \mathrm{ml}^{-1}$ penicillin and $100 \mu \mathrm{g} \mathrm{ml}^{-1}$ streptomycin at $37^{\circ} \mathrm{C}$ and $5 \% \mathrm{CO}_{2}$. The assays for antimicrobial activity were carried out as described previously. ${ }^{17}$ The cytotoxicity against MonoMac6 cells was determined in an 2,3-bis(2-methoxy-4-nitro-5-sulfophenyl)-2H-tetrazolium-5-carboxanilide sodium-based cell viability assay. ${ }^{18}$

The 972-bp human CXCL10 promoter $(-875$ to +97 relative to the transcription start site) was cloned into the pGL4 basic vector (Promega, Mannheim, Germany) to generate the hCXCL10 promoter-driven luciferase reporter plasmid. The plasmid pRL-EF1 $\alpha$ for normalizing transfection efficiency was obtained from Promega. The NF-кB-, Stat1- and IRF-driven reporter plasmids pNFKB-Luc, pGAS-Luc and pISRE-Luc, respectively, were obtained from Clontech (Saint-Germain-en-Laye, France). Transient transfections of MonoMac6 cells were performed by electroporation (Bio-Rad, Munich, Germany, Gen Pulser) $3 \times 10^{7}$ cells ml $^{-1}$ in $0.4 \mathrm{ml} \mathrm{RPMI} 1640$ medium 
Table $2{ }^{1} \mathrm{H}(400 \mathrm{MHz})$ and ${ }^{13} \mathrm{C}(101 \mathrm{MHz})$ NMR of ganodermycin in $\mathrm{CDCl}_{3}$

\begin{tabular}{llr}
\hline Position & \multicolumn{1}{c}{$\delta_{H}$} & \multicolumn{1}{c}{$\delta_{C}$} \\
\hline 1 & $2.41(\mathrm{tt}, 12.3,3.5)$ & $42.2(\mathrm{~d})$ \\
2 & $2.09,1.47(\mathrm{~m})$ & $28.7(\mathrm{t})$ \\
3 & $1.92,1.55(\mathrm{~m})$ & $28.3(\mathrm{t})$ \\
4 & $3.22(\mathrm{ttd}, 12.2,3.5,1.8)$ & $36.7(\mathrm{~d})$ \\
5 & - & $181.1(\mathrm{~s})$ \\
$1^{\prime}$ & - & $155.9(\mathrm{~s})$ \\
$2^{\prime}$ & $6.88(\mathrm{~s})$ & $138.4(\mathrm{~d})$ \\
$3^{\prime}$ & - & $197.5(\mathrm{~s})$ \\
$4^{\prime}$ & $3.51(\mathrm{~s})$ & $66.3(\mathrm{~d})$ \\
$5^{\prime}$ & - & $62.4(\mathrm{~s})$ \\
$6^{\prime}$ & $1.32(\mathrm{~s})$ & $19.1(\mathrm{q})$ \\
$7^{\prime}$ & $1.48(\mathrm{~s})$ & $25.0(\mathrm{q})$ \\
$8^{\prime}$ & $9.49(\mathrm{~d}, 1.8)$ & $194.8(\mathrm{~d})$ \\
\hline
\end{tabular}

containing 25 mM HEPES buffer together with $40 \mu$ g of the indicated plasmids at $200 \mathrm{~V}$ and $975 \mu \mathrm{F}^{19}$ After electroporation the cells were seeded at $1 \times 10^{6}$ cells ml ${ }^{-1}$ RPMI 1640 medium containing $10 \%$ fetal calf serum in a 24-well plate with and without test compounds, and luciferase expression was induced with $1 \mu \mathrm{g} \mathrm{ml}^{-1}$ LPS and $10 \mathrm{ng} \mathrm{ml}^{-1}$ IFN- $\gamma$. Luciferase activity was measured $4 \mathrm{~h}$ after induction using the luciferase assay system (Promega) according to the manufacturer's instructions with a luminometer.

For analyzing CXCL10 synthesis, MonoMac6 cells were starved for $16 \mathrm{~h}$ in RPMI 1640 medium containing $0.5 \%$ fetal calf serum, pretreated for $1 \mathrm{~h}$ with the test compound and subsequently induced with $1 \mu \mathrm{g} \mathrm{ml}^{-1}$ LPS and $10 \mathrm{ng} \mathrm{ml}^{-1}$ IFN- $\gamma$ for additional $16 \mathrm{~h}$. Subsequently, the cells were centrifuged and the cell culture supernatant was analyzed using the CXCL10 ELISA kit (R\&D Systems, Wiesbaden-Nordenstadt, Germany) according to the manufacturer's instructions.

\section{CONFLICT OF INTEREST}

The authors declare no conflict of interest.

\section{ACKNOWLEDGEMENTS}

This work was supported by a grant from the Stiftung Rheinland-Pfalz für Innovation. We thank Professor Dr T Anke for providing Gonoderma applanatum (IBWF09003), Dr N Hanold for mass spectrometric analyses and A Meffert for expert technical assistance.
1 Viola, A. \& Luster, A. D. Chemokines and their receptors: drug targets in immunity and inammation. Annu. Rev. Pharmacol. Toxicol. 48, 171-197 (2008).

2 Lee, E. Y., Lee, Z.- H. \& Song, Y. W. CXCL10 and autoimmune diseases. Autoimmun. Rev. 8, 379-383 (2009).

3 Groom, J. R. \& Luster, A. D. CXCR3 ligands: redundant, collaborative and antagonistic functions. Immunol. Cell Biol. 89, 207-215 (2011).

4 Nishimura, M., Kuboi, Y., Muramoto, K., Kawano, T. \& Imai, T. Chemokines as novel therapeutic targets for inammatory bowel disease. Contemporary challenges in autoimmunity. Ann. NY Acad. Sci. 1173, 350-356 (2009).

5 Tamassia, N. et al. Molecular mechanisms underlying the synergistic induction of CXCL10 by LPS and IFN- $\gamma$ in human neutrophils. Eur. J. Immunol. 37, 2627-2634 (2007).

6 Mackay, C. R. Moving targets: cell migration inhibitors as new anti-inflammatory therapies. Nat. Immunol. 9, 988-998 (2008).

7 Numata, A., Hokimoto, K., Takemura, T., Matsunaga, S. \& Morita, R. Plant constituents biologically active on insects. II. Juvabione analogs from Abies sachalinensis Mast. (1). Chem. Pharm. Bull. 31, 436-442 (1983).

8 Nishida, M. et al. Hymenoic acid, a novel specific inhibitor of human DNA polymerase $\lambda$ from a fungus of Hymenochaetaceae sp. Bioorg. Med. Chem. 16, 5115-5122 (2008).

9 Barrero, A. F., Sanchez, J. F., Alvarez-Manzaneda, R. E. J. \& Muñoz Dorado, M. Sesquiterpenoids related to juvabione in Abies pinsapo. Phytochemistry 28, 2617-2619 (1989).

10 Lee, H.- S., Park, S. Y., Sim, C. J., Rho, J.- R. \& Phorbasins, G.- I. Three new diterpenoids from the sponge Phorbas gukulensis. Chem. Pharm. Bull. 56, 1198-1200 (2008).

11 Jang, K. H. et al. Polyoxygenated diterpenes from the sponge Phorbas sp. J. Nat. Prod. 71, 1701-1707 (2008)

12 Bowers, W. S., Thompson, H. M. \& Uebel, E. C. Juvenile hormone. Identification of an active compound from balsam fir. Science 154, 1020-1021 (1966).

13 Erkel, G., Wisser, G. \& Anke, T. Influence of the fungal NF-kB inhibitor panepoxydone on inflammatory gene expression in MonoMac6 cells. Int. Immunopharmacol. 7, 612-624 (2007).

14 Spurrell, J. C. L., Wiehler, S., Zaheer, R. S., Sanders, S. P. \& Proud, D. Human airway epithelial cells produce IP-10 (CXCL10) in vitro and in vivo upon rhinovirus infection. Am. J. Physiol. Lung Cell Mol. Physiol. 289, L85-L95 (2005).

15 White, T. J., Bruns, T., Lee, S. \& Taylor, J. Amplification and direct sequencing of fungal ribosomal RNA genes for phylogenetics in PCR Protocols: A Guide to Methods and Applications (eds. Innis, M.A., Gelfand, D. H., Sninsky, J. J. and White, T.J.) pp 315322 (Academic Press, San Diego, 1990).

16 Gottlieb, H. E., Kotlyar, V. \& Nudelman, A. NMR chemical shifts of common laboratory solvents as trace impurities. J. Org. Chem. 62, 7512-7515 (1997).

17 Rether, J., Erkel, G., Sterner, O. \& Anke, T. Inhibition of TNF- $\alpha$ promoter activity and synthesis by A11-99-1, a new cyclopentenone from the ascomycete Mollisia melaleuca. Z. Naturforsch. 60c, 478-484 (2005).

18 Roehm, N. W., Rodgers, G. H., Hatfield, S. M. \& Glasebrook, A. L. An improved colorimetric assay for cell proliferation and viability utilizing the tetrazolium salt XTT. J. Immunol. Methods 142, 257-265 (1991).

19 Jung, M., Triebel, S., Anke, T., Richling, E. \& Erkel, G. Influence of apple polyphenols on inflammatory gene expression. Mol. Nutr. Food Res. 53, 1263-1280 (2009). 